\title{
Dietary Ganglioside Intake and Serum Ganglioside Concentration among Indonesian Toddlers
}

\author{
Frieda Handayani Kawanto ${ }^{1}$, Bertram Fong ${ }^{2}$, Rebecca Cannan ${ }^{2}$, Fatima Safira Alatas ${ }^{1}$, \\ Selly Mulyadi ${ }^{3}$, Yolin Marlisa ${ }^{3}$, Miftakh Nur Rahman ${ }^{3}$, Agus Firmasyah ${ }^{1, *}$ \\ ${ }^{1}$ Faculty of Medicine, Division of Paediatric Gastroenterology, Department of Child Health, \\ Universitas Indonesia, Jakarta 10430, Indonesia \\ ${ }^{2}$ Fonterra Research and Development Centre, Private Bag 11029, Palmerston North 4442, New Zealand \\ ${ }^{3}$ PT. Prodia Diacro Laboratories, Jl. Kramat Raya No. 150, Jakarta Pusat - 10430, Indonesia \\ *Corresponding author: agusfirmansyah@yahoo.com
}

Received December 22, 2018; Revised January 29, 2019; Accepted March 05, 2019

\begin{abstract}
Gangliosides are major components in the human brain. The incorporation of gangliosides into the developing human brain is rapid, increasing from the third trimester through to the first 4-5 years of life, coinciding with the neuronal and glial differentiation and maturation process. It is generally accepted that breast-fed infants consume higher levels of gangliosides than formula-fed infants. However, the dietary ganglioside intake status at the toddler age period is unclear, given that toddlers are still going through a rapid growth and learning phase. The aim of this study was to provide an understanding of the dietary ganglioside sources and intakes for a cross-section of Indonesian toddlers and to determine any correlation with their serum ganglioside concentrations. Toddlers (150) were recruited from the Pejaten, South Jakarta, region. The dietary ganglioside intake was determined from food intake data collected over 2 days using a food frequency questionnaire. The ganglioside levels in the food and the blood were determined using a high performance liquid chromatography-mass spectrometry method. The average dietary ganglioside intake and the serum ganglioside content of Indonesian toddlers were $6.13 \pm 0.56 \mathrm{mg} / \mathrm{day}$ and $13.2 \pm 3.3 \mathrm{mg} / \mathrm{L}$ respectively. Growing-up milk powders contributed $71.8 \%$ of the daily total ganglioside intake, and major dietary ganglioside contributor. [1] No positive correlation was observed between the dietary ganglioside intake and the serum ganglioside concentration over the 2-day study period. Long term dietary and intervention studies are required to provide a clearer picture of the impact of dietary gangliosides on serum ganglioside levels.
\end{abstract}

Keywords: ganglioside, Indonesian toddler, dietary intake

Cite This Article: Frieda Handayani Kawanto, Bertram Fong, Rebecca Cannan, Fatima Safira Alatas, Selly Mulyadi, Yolin Marlisa, Miftakh Nur Rahman, and Agus Firmasyah, "Dietary Ganglioside Intake and Serum Ganglioside Concentration among Indonesian Toddlers.” Journal of Food and Nutrition Research, vol. 7, no. 3 (2019): 191-200. doi: 10.12691/jfnr-7-3-3.

\section{Introduction}

Gangliosides (GAs) are a large family of bioactive sialic acid containing glycolipids that are categorised into different classes according to the glycan structure attached to the ceramide moiety. They are typically annotated using the nomenclature (e.g. GD3, GM3) that was introduced by Svennerholm [2], rather than the more complex IUPAC system [3]. Further complexity within each GA class comes from the different fatty acid compositions associated with the ceramide moiety. Although GAs are found in various organs and tissues in the human body, they are particularly concentrated in nervous tissue and the brain, making up $10-12 \%$ of the lipid material [4,5]. GAs are incorporated rapidly into the human brain during the second trimester through to the first 5 years of life [6]. Although the actual mechanism by which dietary GAs work is still poorly understood, they are thought to play important roles in memory and higher cognitive function, as their concentration and their distribution change throughout the early stages of brain development.

The role that GAs play in neural and brain development has been well reviewed by McJarrow et al. [7], Ryan et al. [8] and Palmano et al. [4]. In addition to this role, GAs have also been implicated in various anti-infection and immunity processes $[9,10,11]$. The GAs in human milk are mostly associated with the milk fat globule membrane and function as a "decoy" target receptor for bacterial adhesion, hence interfering with pathogenic binding to the intestine and preventing infection [9].

Mature human milk contains high concentrations of GAs (from $14.8 \pm 8$ to $25.3 \pm 15.7 \mathrm{mg} / \mathrm{L}[12,13]$ ), and there are even higher concentrations in colostrum $(26.8 \pm 16.4 \mathrm{mg} / \mathrm{L}$ [13]), when compared with the concentrations that are typically measured in infant formula (from 2 to $16 \mathrm{mg} / \mathrm{L}$ [13]). Consequently, it is 
generally accepted that the breast-fed infant consumes more GAs than its formula-fed counterpart. However, there is limited information on the dietary total GA (TGA) intake by toddlers, with only one recent publication for Malaysian toddlers [14]. These researchers estimated that the TGA intake was approximately $5.86 \pm 0.56 \mathrm{mg} /$ day, with growing-up milk powders (GUMPs) being the major contributor to dietary GAs. Furthermore, this study [14] did not find a correlation between dietary TGA intakes and serum TGA levels. However, long term intervention studies in adults [15] and infants [16,17], at high GA levels (43 and 12-15 mg/day respectively), showed an increase in serum GA levels.

The importance of GAs has not been restricted only to developing infants. Positive outcomes have been reported when GAs have been used as a therapeutic agent for the treatment of neurological disorders such as cerebral palsy [18] and cerebrovascular, Alzheimer's and Parkinson's diseases [19,20,21].

Currently, there is no information on the dietary GA intake of Indonesian toddlers. Given the importance of GAs in various biological processes, including brain development, and given that GAs are rapidly incorporated into the human brain during the first 5 years of life [6], it is important to have an understanding of the dietary intake of GAs by Indonesian toddlers.

The aim of this study was to gain an understanding of the GA content in local Indonesian foods, and in the diet and the serum of Indonesian toddlers. Although there is no recommended intake for GAs, the knowledge gained from this study will help health care professionals to make dietary decisions that aid the normal growth of toddlers and the development of various biological systems such as immune, visual and cognitive performance.

\section{Methods}

\subsection{Study Design and Recruitment of Toddlers}

In this study, a cross-section of 150 Indonesian toddlers was surveyed to determine their dietary GA intake, their blood serum GA concentration and whether there was any correlation between the dietary GA intakes and the blood serum GA concentrations.

The toddlers in the study were recruited via local community centres in the Kelurahan Pejaten, Kecamatan Pasar Minggu, South Jakarta region. Permission to visit families with young children was first obtained from local community administration centres (known locally as Rukun Warga and Rukun Tetangga). The study was introduced to these families during the home visits. Only toddlers with parental permission and that met the study criteria were accepted into the study.

\subsection{Inclusion Criteria}

Toddler age between 15 and 21 months.

Toddler in good health at the time of recruitment, during the research duration and at the time of blood sampling.

Parent able to fill out the food frequency questionnaire.

\subsection{Exclusion Criteria}

Toddler with a chronic or serious illness.

Toddler receiving medication.

Toddler unwell physically at acceptance, during the research duration or at the time of blood sampling.

Toddler whose parents refused to sign the informed consent or the agreement.

Parent who appeared to be unable to fill out the food frequency questionnaire with accepted accuracy.

\subsection{Sample Size}

A study for a sample size of 130 toddlers was computed, to provide a power of $80 \%$ with the statistical significance set at the 5\% level. This calculation was based on the assumption that the standard deviation for the serum TGAs was $2.78 \mathrm{mg} / 100 \mathrm{~mL}$ [22]. The final sample size was rounded to 150 toddlers to ensure statistical power.

A few extra families/toddlers were also recruited as it was anticipated that some families/toddlers would drop out of the study.

\subsection{Dietary Intake Data Collection}

Clinical assessments of the toddlers were conducted at the University of Indonesia Clinic Outpost by a general medical practitioner. Once the toddler was confirmed in the study, a signed informed consent form was obtained from the parents. Interviews with the parents were conducted by a nutritionist to obtain information on the types of foods consumed by the toddlers. The parents were trained on how to record the types and the amounts of foods and beverages consumed by the toddlers and how to fill out the food frequency questionnaire (including food recall information).

The food intake of each toddler over 2 days was recorded by its parents. Blood samples were drawn on the third day at the University of Indonesia Clinic Outpost. At the same time, the food frequency questionnaire was checked by the nutritionist and any uncertainty or ambiguous information was clarified with the parent. All food intake data were entered into a computer database for subsequent statistical analysis.

\subsection{Food GA Analysis}

Measurement of the GAs in foods was carried out at the Fonterra Research and Development Centre, Palmerston North, New Zealand. Based on the list of dietary foods and beverages consumed by the toddlers, food items were purchased from local supermarkets and air freighted to Palmerston North, New Zealand. Fish samples, approximately 100-150 g each, were purchased, packed, labelled and shipped frozen. All equivalent animal meat and dairy samples were sourced from local supermarkets in Palmerston North, New Zealand.

All meat and fish samples were cut into small pieces prior to freeze drying. A sample (20 g) was weighed out and freeze dried. The freeze-dried sample was then milled into a powder using a domestic coffee grinder. Dry foods such as biscuits and cakes were milled without freeze drying. Samples, approximately 0.1-0.2 g of freeze-dried 
powder or dry sample, were weighed into Kimax tubes (10 $\mathrm{mL})$ together with water $(0.4 \mathrm{~mL})$. They were mixed and allowed to rehydrate for $10 \mathrm{~min}$ prior to lipid extraction. Liquid samples $(0.5 \mathrm{~mL})$ were extracted directly. Milk powder samples were made up as a $10 \%$ solution in water. Aliquots $(0.5 \mathrm{~mL})$ of these rehydrated samples were used for analysis. GA extraction was conducted using the method described by Fong et al. [23].

Briefly, water $(0.5 \mathrm{~mL})$ at room temperature was added to the homogenate, followed by methanol $(2.7 \mathrm{~mL})$ and chloroform $(1.35 \mathrm{~mL})$. The mixture was allowed to rock gently for $30 \mathrm{~min}$ on a rocker before centrifugation at $2000 \mathrm{~g}$ for $30 \mathrm{~min}$. The supernatant was transferred to a 15-mL Kimax tube and the pellet was re-extracted using water $(0.5 \mathrm{~mL})$ and chloroform/methanol $(1: 2,2 \mathrm{~mL})$. After mixing and centrifugation (2000 $\mathrm{g}$ for $30 \mathrm{~min}$ ), the supernatants were pooled and the pellet was discarded. Solvent partition of the supernatant was achieved by the addition of water $(1.3 \mathrm{~mL})$, followed by centrifugation (2000 $\mathrm{g}$ for $30 \mathrm{~min}$ ). The upper phase was transferred to a 10 -mL volumetric flask. Potassium chloride $(0.01 \mathrm{M}, 0.5 \mathrm{~mL})$ was added to the remaining lower phase and any interfacial fluff (minimal) and was centrifuged (2000 $\mathrm{g}$ for $20 \mathrm{~min}$ ). The upper phase was pooled into the $10-\mathrm{mL}$ volumetric flask and made up to the mark with methanol (50\%).

The upper phase, or GA-containing extract, was analysed for GAs using high performance liquid chromatography-mass spectrometry (HPLC-MS), as described by Fong et al. [23]. The HPLC analysis was performed on an Agilent 1100 series HPLC system (Santa Clara, CA, USA) that was interfaced to an LTQ-Orbitrap ${ }^{\mathrm{TM}}$ mass spectrometer (Thermo Electron Corporation, Waltham, MA, USA) with an electrospray ionisation probe. The resolving power of the LTQ-Orbitrap ${ }^{\mathrm{TM}}$ mass spectrometer was used to filter post analysis for known masses of GA species that were present within each class of GA (GM1, GM2, GM3, GD3, GD1a, GD1b, GT1b, GQ1b), which were measured using external standard methodology.

\subsection{Serum GA Analysis}

Blood from the toddlers was drawn into Vacutainer blood collection tubes and immediately placed into a portable dry-ice cooler (temperature between 2 and $8^{\circ} \mathrm{C}$ ), before transfer to the testing laboratory. In the testing laboratory, serum samples were prepared, aliquoted into cryogenic vials and stored at $-80^{\circ} \mathrm{C}$ prior to GA analysis.

Blood serum GA analysis was conducted using HPLCMS, in a similar fashion to that described for food GA analysis, except that an Agilent UPLC system (Agilent 1290, Santa Clara, CA, USA) was interfaced to an Agilent triple quadrupole mass spectrometer (Agilent 6460, Santa Clara, CA, USA), which was set to analyse the GAs in multiple reaction monitoring mode as described by Ma et al. [13]. Blood serum samples $(0.5 \mathrm{~mL})$ were extracted and made to $10 \mathrm{~mL}$ in $50 \%$ methanol. The eluate from the HPLC was introduced into the mass spectrometer using an Agilent jet stream-electrospray ionisation source in negative polarity mode. Ions were generated and focused using the following conditions: a drying gas temperature of $300^{\circ} \mathrm{C}$, a drying gas flow of $10 \mathrm{~L} / \mathrm{min}$ and a nebuliser pressure of 35 psi. The sheath gas temperature was set to $350^{\circ} \mathrm{C}$, with a flow of $10 \mathrm{~L} / \mathrm{min}$. The capillary and nozzle voltages were set to 4000 and $500 \mathrm{~V}$ respectively.

\subsection{Statistical Analysis}

Statistical analysis was carried out using SPSS (version 20, SPSS Inc., New York, NY, USA) and Minitab (version 17.2.10, Minitab Inc., State College, PA, USA) to determine any relationship between the dietary GA intakes and the serum GA levels in the toddlers, and any condition that affected the serum GA level. A $p$ value of $<0.05$ was considered to be statistically significant.

\section{Results}

\subsection{Participant Profiles}

The background information for the toddlers and their parents is presented in Table 1 . Of the 150 toddlers who participated in this study, 63\% $(n=94)$ were male and $37 \%(n=56)$ were female. The mean age of the toddlers was 17 months. The majority of the toddlers (97\%) were full term birth and $89 \%$ were classed as having normal weight at birth.

Table 1. Profiles and background of toddlers and parents $(n=150)$

\begin{tabular}{|c|c|c|}
\hline Characteristics & $n(\%)$ & Mean (range) \\
\hline \multicolumn{3}{|l|}{ Demographics } \\
\hline \multicolumn{3}{|l|}{ Toddler gender } \\
\hline Male & $94(62.7)$ & \\
\hline Female & $56(37.3)$ & \\
\hline Toddler age (months) & & $17(12-21)$ \\
\hline Father age (years) & & $35(20-58)$ \\
\hline \multicolumn{3}{|l|}{ Education level $^{\mathrm{a}}$} \\
\hline Low education & $22(14.7)$ & \\
\hline Secondary education & $80(53.3)$ & \\
\hline Higher education & 46 (30.7) & \\
\hline None & $2(1.3)$ & \\
\hline Mother age (years) & & $30(21-41)$ \\
\hline \multicolumn{3}{|l|}{ Education level } \\
\hline Low education & $44(29.3)$ & \\
\hline Secondary education & $60(40.0)$ & \\
\hline Higher education & $46(30.7)$ & \\
\hline \multicolumn{3}{|l|}{ Birth history } \\
\hline \multicolumn{3}{|l|}{ Birth weight category } \\
\hline Low birth weight & $10(6.7)$ & \\
\hline Normal birth weight & $133(88.7)$ & \\
\hline Small for gestational age & $0(0)$ & \\
\hline Macrosomia (> $4000 \mathrm{~g}$ ) & $6(4.0)$ & \\
\hline Unknown & $1(0.7)$ & \\
\hline \multicolumn{3}{|l|}{ Delivery } \\
\hline Vaginal & $104(69.4)$ & \\
\hline Caesarean section & $46(30.7)$ & \\
\hline \multicolumn{3}{|l|}{ Labour } \\
\hline Premature & $5(3.3)$ & \\
\hline Normal & $145(96.7)$ & \\
\hline \multicolumn{3}{|l|}{ Anthropometry } \\
\hline Weight (kg) & & $10.1(0.1)$ \\
\hline Height (cm) & & $78.9(0.2)$ \\
\hline Head circumference (cm) & & $46.0(0.1)$ \\
\hline \multicolumn{3}{|l|}{ a Education level. } \\
\hline \multicolumn{3}{|c|}{$\begin{array}{l}\text { Low education: junior high school ( } 9 \text { years of education completed). } \\
\text { Secondary education: senior high school ( } 12 \text { years of education } \\
\text { completed). } \\
\text { Higher education: university bachelor's degree or diploma. }\end{array}$} \\
\hline
\end{tabular}


The mean ages of the mothers and the fathers were 30 and 35 years respectively. All the parents were educated in the Indonesian system, with $27 \%$ of mothers and $15 \%$ of fathers having completed 9 years of junior high school (sekolah menengah pertama) and $41 \%$ of mothers and $53 \%$ of fathers having finished 12 years of senior high school (sekolah menengah atas). Approximately a third of both parents (32\%) had tertiary education.

Table 2. Breast feeding and complementary feeding practices $(n=150)$

\begin{tabular}{lc}
\hline & $n(\%)$ \\
\hline Had the toddler ever been breast fed during its life? & $145(96.7)$ \\
Yes & $5(3.3)$ \\
No & \\
Had the toddler been breast fed before the study? & $145(96.7)$ \\
Yes & $5(3.3)$ \\
No & \\
Was the toddler breast fed during this study? & $52(35)$ \\
Yes & $98(65)$ \\
No & \\
Did the toddler consume formula milk during the & \\
2-day study? & $92(61.3)$ \\
Yes & $58(38.7)$ \\
No & \\
Did the toddler consume lactose-free formula milk & \\
during the 2-day study? & $6(4.0)$ \\
Yes & $144(96.0)$ \\
No & \\
Did the toddler have a cows' milk allergy? & $2(1.3)$ \\
Yes & $148(98.7)$ \\
No &
\end{tabular}

Most of the toddlers (97\%) were breast fed as infants. Only 5 (3\%) had never been breast fed (Table 2). The mean weaning age for the toddlers in this study was 6 months. During this study, only 52 toddlers (35\%) were still receiving some breast milk. Of these 52 toddlers receiving breast milk, 42 were also receiving GUMP. Also,
$61 \%$ of the toddlers were complementarily fed with GUMP on top of their normal diet.

\subsection{GA Intake}

The average daily dietary TGA intake for the Indonesian toddlers was determined from the 48-h food record data. The dietary sources of GA intake data were categorised into five different food groups (Table 3 Table 6). The fish category comprised fresh and processed fish, and the meat category included white meats, red meats, offal meats and eggs. The bakery foods category included breads, biscuits and cakes. Condensed milk, whole milk powder, UHT milk, ice cream, cheeses and liquid milks were part of the dairy foods category. All the toddler milk powders were grouped into the GUMP category. The results indicated that GUMPs were the major contributors (71.8\%) to the dietary GA intake of the toddlers, followed by meat (21.2\%) and dairy foods (4.7\%) (Table 7). Bakery foods and fish were only minor contributors to the dietary GA intake, at $0.8 \%$ and $1.5 \%$ respectively (Table 7 ). Over one-third (35\%) of the toddlers were also receiving breast milk during the study period. However, the dietary GA contribution from breast milk for these toddlers was not included in this study because of the logistics of measuring the actual volumes consumed.

Although GUMPs were the major contributors to the average dietary TGA intake, they were consumed by only 92 (61\%) of the Indonesian toddlers. Within this group, there were large variations in the daily TGA intake between individuals, ranging from 1.76 to $10.69 \mathrm{mg}$ for the $25^{\text {th }}$ and $75^{\text {th }}$ percentiles respectively (Table 7 ). The large variation in the TGA intake from GUMPs was due to both the varied consumption rate of these products and their wide TGA content. In this study, 12 different GUMP brands were consumed (Table 3 ) by the toddlers, with the TGA content ranging from 2.80 to $16.10 \mathrm{mg} / 100 \mathrm{~g}$.

Table 3. GA content (mg/100 g) in GUMPs and dairy foods consumed by Indonesian toddlers

\begin{tabular}{|c|c|c|c|}
\hline Sample description & GM3 & GD3 & TGAs \\
\hline GUMP 1 (PediaSure) & & 5.07 & 5.07 \\
\hline GUMP 2 (S26 Procal Stage 3) & & 11.68 & 11.68 \\
\hline GUMP 3 (Bebelac 3) & & 5.39 & 5.39 \\
\hline GUMP 5 (Dancow Batita (1-3 years) vanilla) & & 2.80 & 2.80 \\
\hline GUMP 6 (Frisian Flag (1-3 years) vanilla) & & 4.53 & 4.53 \\
\hline GUMP 7 (Lactogrow 3 plain) & & 11.26 & 11.26 \\
\hline GUMP 8 (Nutrilon plain) & & 16.10 & 16.10 \\
\hline GUMP 9 (SGM 1+ Eksplor plain) & & 10.58 & 10.58 \\
\hline GUMP 10 (Similac Gain Plus 3 vanilla) & & 8.41 & 8.41 \\
\hline GUMP 11 (Sustagen Junior 1+) & & 4.61 & 4.61 \\
\hline GUMP 12 (Vidoran 1+ Xmart (1-3 years) vanilla) & & 7.51 & 7.51 \\
\hline UHT milk 1 (Indomilk - 2.5\% fat) & & 0.59 & 0.59 \\
\hline UHT milk 2 (Dancow - 2.5\% fat) & & 1.09 & 1.09 \\
\hline UHT milk 3 (Bear Brand - Nestlé) & & 0.91 & 0.91 \\
\hline UHT milk 4 (Susu Ultra Mimi 2.5\% fat) & & 0.90 & 0.90 \\
\hline UHT milk 6 (Frisian Flag chocolate 3\% fat) & & 0.68 & 0.68 \\
\hline Condensed milk (Pams, New Zealand) & & 1.04 & 1.04 \\
\hline Cheddar cheese (Budget) & & 0.81 & 0.83 \\
\hline Processed cheese (Chesdale Cheddar) & 0.11 & 3.24 & 3.35 \\
\hline Ice cream (vanilla) New Zealand & & 2.05 & 2.05 \\
\hline Ice cream (with chocolate/caramel) New Zealand & & 1.28 & 1.28 \\
\hline Whole milk (homogenised, 3.5\% fat) & & 1.37 & 1.37 \\
\hline Whole milk powder & & 11.20 & 11.20 \\
\hline Skim milk powder & & 8.80 & 8.80 \\
\hline Milk chocolate (Cadbury) & & 0.59 & 0.59 \\
\hline
\end{tabular}


Table 4. GA content ( $\mathrm{mg} / 100 \mathrm{~g}$ fresh product) in meats and eggs consumed by Indonesian toddlers

\begin{tabular}{|c|c|c|c|c|c|c|c|c|c|}
\hline & GM1 & GM2 & GM3 & GM4 & GD3 & GD1a & GD1b & GQ1b & TGAs \\
\hline Chicken drum stick & & 1.62 & 0.39 & & 0.02 & 0.01 & & & 2.05 \\
\hline Chicken sausages & & 1.66 & 0.08 & & 0.12 & 0.00 & & & 1.87 \\
\hline Chicken feet & & 2.08 & 0.36 & & 0.03 & 0.01 & & & 2.48 \\
\hline Chicken gizzard & & & 3.74 & & 0.17 & 0.03 & & & 3.93 \\
\hline Chicken intestine & & & 47.99 & 2.32 & 8.66 & 0.99 & 0.07 & & 60.05 \\
\hline Chicken heart & & & 2.91 & 0.00 & 0.63 & 0.03 & & & 3.57 \\
\hline Chicken liver $^{\mathrm{a}}$ & & & 26.78 & 1.66 & 0.62 & 0.90 & & & 29.02 \\
\hline Chicken thigh (+ skin) & & & 1.08 & & 0.28 & & & & 1.37 \\
\hline Chicken breast (+ skin) & & & 0.75 & & 0.20 & & & & 0.95 \\
\hline Chicken nugget $^{\mathrm{a}}$ & & & 1.43 & & 0.11 & & & & 1.54 \\
\hline Offal (cow large intestine) & & & 2.15 & & 0.08 & 0.52 & 0.04 & 0.05 & 2.84 \\
\hline Offal (cow small intestine) & & & 4.15 & & 0.09 & 0.56 & 0.06 & 0.05 & 4.92 \\
\hline Cow liver & & & 0.67 & & 0.20 & 5.06 & & & 5.93 \\
\hline Minced beef (lean) & & & 0.46 & & 0.02 & & & & 0.48 \\
\hline Beef blade steak (lean) & & & 0.82 & & 0.08 & & & & 0.91 \\
\hline Beef rump (with fat) & & 2.02 & 0.11 & & 0.12 & 0.01 & & & 2.25 \\
\hline Beef floss & & 1.11 & 0.19 & & 0.16 & 0.02 & & & 1.47 \\
\hline Beef sausage & & 1.51 & 0.07 & & 0.11 & 0.00 & & & 1.69 \\
\hline Beef ribs & & 0.05 & 6.12 & & 0.14 & 0.17 & 0.01 & & 6.50 \\
\hline Duck breast & & 1.02 & 0.64 & & 0.27 & 0.24 & 0.10 & & 2.27 \\
\hline Lamb rump steak & & & 4.85 & & 0.10 & 0.23 & & & 5.18 \\
\hline Quail egg yolk 1 & 1.10 & 0.53 & 1.95 & 0.83 & 0.69 & 0.59 & & & 5.68 \\
\hline Quail egg yolk 2 & 0.65 & 2.18 & 4.26 & 0.96 & 0.87 & 0.25 & & & 9.17 \\
\hline Quail egg 1 & 0.53 & 0.25 & 0.94 & 0.40 & 0.33 & 0.28 & & & 2.73 \\
\hline Quail egg 2 & 0.30 & 1.01 & 1.96 & 0.44 & 0.40 & 0.12 & & & 4.23 \\
\hline Chicken egg ${ }^{\mathrm{b}}$ & & & 0.06 & 1.02 & & & & & 1.08 \\
\hline Chicken egg yolk ${ }^{\mathrm{b}}$ & & & 11.96 & 3.32 & 0.61 & & & & 15.90 \\
\hline Caged chicken egg & & & 0.94 & 0.46 & 0.09 & & & & 1.49 \\
\hline Caged chicken egg yolk & & & 3.30 & 3.40 & 0.31 & & & & 7.01 \\
\hline Duck egg $1^{\mathrm{a}, \mathrm{b}}$ & & & & 0.74 & 0.00 & & & & 0.77 \\
\hline Duck egg $2^{\mathrm{a}, \mathrm{b}}$ & & & & 0.61 & 0.00 & & & & 0.65 \\
\hline Duck egg yolk & & & 2.68 & 1.86 & 0.50 & & & & 5.05 \\
\hline Duck egg yolk $^{\mathrm{b}}$ & & & 2.54 & 1.49 & 0.37 & & & & 4.40 \\
\hline
\end{tabular}

${ }^{\mathrm{a}}$ Khor et al. [13].

${ }^{\mathrm{b}}$ Free range.

Table 5. GA content (mg/100 g fresh product) in seafood and processed fish consumed by Indonesian toddlers

\begin{tabular}{|c|c|c|c|c|c|}
\hline & GM2 & GM3 & GD3 & GD1a & TGAs \\
\hline Sardine (Sardina pilchardus) & & 2.48 & 0.01 & & 2.49 \\
\hline Basa fish (Pangasius bocourti) & & 2.18 & 0.06 & & 2.24 \\
\hline Carp - common (Cyprinus carpio) & & 0.13 & 0.06 & & 0.19 \\
\hline Gourami (Osphronemus goramy) & 0.01 & 0.21 & 0.08 & & 0.30 \\
\hline Mackerel tuna (Euthynnus affinis) & & 0.00 & 0.05 & & 0.06 \\
\hline Mackerel - chub (Scomber japonicus) & 0.19 & 0.05 & & & 0.24 \\
\hline Promfret (Bramidae) & & 0.06 & 0.03 & & 0.09 \\
\hline Starry triggerfish (Abalistes stellaris) & 0.01 & 0.01 & 0.00 & & 0.02 \\
\hline Tilapia (Oreochromis mossambicus) & 0.04 & 0.00 & 0.04 & & 0.07 \\
\hline Yellowstripe scad (Selaroides leptolepis) & & 1.44 & 0.02 & & 1.46 \\
\hline Milkfish (Chanos chanos) & & 0.11 & & & 0.11 \\
\hline Catfish & & 0.06 & & & 0.06 \\
\hline Island mackerel (Rastrelliger faughni Matsui) & & 5.86 & 0.23 & & 6.09 \\
\hline Dried anchovy - Stolephorus indicus ${ }^{\mathrm{a}}$ & & 9.80 & 0.05 & & 9.85 \\
\hline Tuna (yellow fin) ${ }^{\mathrm{a}}$ & & 0.20 & 0.01 & & 0.22 \\
\hline Crab meat (frozen) ${ }^{\mathrm{a}}$ & & 0.44 & 0.06 & & 0.50 \\
\hline Squid (frozen tubes) ${ }^{\mathrm{a}}$ & & 0.73 & 0.02 & & 0.75 \\
\hline Prawns/shrimps (Vanemaei) ${ }^{\mathrm{a}}$ & & 0.01 & 0.01 & & 0.02 \\
\hline Salmon (New Zealand) & & 0.98 & 0.11 & & 1.04 \\
\hline Mackerel tuna (Euthynnus affinis) floss & & 0.05 & & & 0.05 \\
\hline Salted fish japu (ikan asin japu) & & 0.08 & & & 0.08 \\
\hline Otak-otak (fishcake with tapioca) & & 0.03 & & & 0.03 \\
\hline Tekwan (mackerel fishcake with tapioca) & & 0.01 & & & 0.01 \\
\hline Tuna nugget $^{\mathrm{a}}$ & & 0.16 & & & 0.16 \\
\hline Panada (tuna fish snack) & & 0.11 & 0.08 & & 0.19 \\
\hline Pempek (mackerel fishcake) & & 0.01 & 0.03 & 0.02 & 0.05 \\
\hline Siomay (fish snack) & & 0.02 & 0.03 & & 0.05 \\
\hline Keropok & & 1.12 & 0.01 & & 1.13 \\
\hline Fishball & & 0.23 & & & 0.23 \\
\hline Fish cracker - raw (Muruku ikan) & & 0.25 & & & 0.25 \\
\hline
\end{tabular}

\footnotetext{
${ }^{a}$ Khor et al. [13].
} 
Table 6. GA content (mg/100 g) in bakery foods and biscuits consumed by Indonesian toddlers

\begin{tabular}{|c|c|c|c|c|c|}
\hline & GM3 & GM4 & GD3 & GD1a & TGAs \\
\hline Wafer biscuit 1 (Tango Coklat) & & & 0.07 & & 0.07 \\
\hline Wafer biscuit 2 (Richeese Nabati Keju) & & & 0.50 & & 0.50 \\
\hline Standard biscuit 1 (Roma Kelapa) & & & 0.08 & & 0.08 \\
\hline Standard biscuit 2 (Milkuat Bungkus Merah) & & & 0.02 & & 0.02 \\
\hline Milk biscuit 1 (Promina) & & & 1.04 & & 1.04 \\
\hline Milk biscuit 2 (Roma Marie Susu) & & & 0.07 & & 0.07 \\
\hline Wheat biscuit 1 (belVita Biasa) & & & 0.05 & & 0.05 \\
\hline Wheat biscuit 2 (Roma Sari Gandum) & & & 0.09 & & 0.09 \\
\hline Cracker 1 (Roma Malkist) & & & 0.00 & & 0.00 \\
\hline Cracker 2 (Oops Crispy Keju) & & & 0.01 & & 0.01 \\
\hline Cream sandwich biscuit 1 (Salai O'lai strawberry) & & & 0.19 & & 0.19 \\
\hline Cream sandwich biscuit 2 (Better chocolate vanilla) & & & 0.48 & & 0.48 \\
\hline Cheese biscuit (salt cheese biscuits) & & & 0.24 & & 0.24 \\
\hline Cake (sponge - New Zealand) & 0.07 & 0.00 & 0.09 & & 0.16 \\
\hline Cake (chiffon cake - Massimo) & 0.57 & 0.15 & 0.29 & & 1.00 \\
\hline Layer cake (Apollo) & 0.20 & 0.05 & 0.05 & & 0.30 \\
\hline Butter-filled sandwich (Julie’s) & & & 0.12 & & 0.12 \\
\hline Doughnut (with cream) & 0.03 & & 0.06 & & 0.09 \\
\hline Pancake (milk, cream, egg) & 0.04 & & 3.37 & & 3.41 \\
\hline Bread & 0.01 & & 0.29 & & 0.30 \\
\hline Egg tart & 0.00 & 0.08 & 0.02 & 0.04 & 0.14 \\
\hline
\end{tabular}

Table 7. Average daily intakes of dietary GAs $(n=150)$ : mean, median and 25th and 75th percentiles Update all median and percentiles with excel data

\begin{tabular}{lcr}
\hline \multirow{2}{*}{ Food source } & \multicolumn{2}{c}{ Daily intake (mg) } \\
\cline { 2 - 3 } & \multicolumn{2}{c}{${\text { Median }\left(25^{\text {th }}, 75^{\text {th }} \text { percentiles }\right)^{-1 \%)}}^{0.02(0.005,0.07)}$} \\
Bakery & $0.05 \pm 0.01(0.8)$ & $0.02(0.01,0.20)$ \\
Dish & $0.09 \pm 0.05(1.5)$ & $0.55(0.08,1.03)$ \\
Meat & $0.29 \pm 0.06(4.7)$ & $0.55(0.25,1.17)$ \\
GUMP & $1.30 \pm 019(21.2)$ & $4.87(1.76,10.69)$ \\
Total & $4.40 \pm 0.57(71.8)$ & $3.13(1.35,8.36)$ \\
\hline
\end{tabular}

Meat, including offal, was consumed by $94 \%$ of the toddlers during this study. Similar to the GUMPs, the dietary GA contribution from meat varied, from 0.25 to $1.17 \mathrm{mg}$ for the $25^{\text {th }}$ and $75^{\text {th }}$ percentiles (Table 7). Again, there was a wide range of TGA content across the various meat products (including offal) that were consumed by the toddlers, with chicken intestine having the highest TGA content (60 mg/100 g, Table 4). Although some dairy foods, such milk powder and liquid milk, have relatively high TGA content (Table 3), they contributed only 4.7\% (Table 7) to the dietary TGA intake of the toddlers. The consumption volumes for dairy products amongst these toddlers were relatively low, with only $42 \%$ of the cohort consuming some dairy products (excluding GUMPs) during the study.

Whereas a reasonably wide range of fish species was consumed by the toddlers, only $28 \%$ ate seafood during the course of this study. The TGA content of the seafood varied from $0.02 \mathrm{mg} / 100 \mathrm{~g}$ in prawns to $9.85 \mathrm{mg} / 100 \mathrm{~g}$ in oily fish such as anchovies (Table 5). The GAs in seafood and bakery foods were only minor contributors to the dietary GA intake of the toddlers in this study.

\subsection{Toddler Serum GA Levels}

The average serum TGA concentration measured in this Indonesian toddler cohort was $13.29 \pm 3.35 \mathrm{mg} / \mathrm{L}$. However, the TGA levels varied widely between individuals, ranging from 7.40 to $30.4 \mathrm{mg} / \mathrm{L}$. GM3 was the major GA that was measured in the blood serum, making up approximately 69-95\% of the TGA intake. GD3 made up only 5-23\%. Other minor GAs that were measured in the blood were GM1, GM2, GD1a and GD1b, making up on average $<1.8 \%$ of the TGAs measured.

\subsection{Correlation between Dietary GA Intake and Serum GA Level}

Statistical analysis did not show a significant correlation $(p>0.05)$ between the dietary GA intakes from any of the five individual food categories with the serum GA levels (Table 8), even for the GUMPs ( $p=0.115$, Table 8), despite their being the major dietary GA contributor. However, a statistically significant correlation $(p=0.002)$ was observed between the dietary TGA (sum of the GA intake across all five food categories) and serum TGA (Table 8). However, this correlation (negative) was both weak $(r=0.246)$ and negative (Figure 1$)$. The points on the scatterplot of the dietary TGA versus serum TGA data (Figure 1) have a wide spread, especially for the lower levels of the dietary intake variable.

Table 8. Correlation between dietary GA level and serum GA level, determined using Spearman Rho correlation

\begin{tabular}{ccc}
\hline \multirow{2}{*}{ Food source (daily) } & \multicolumn{2}{c}{ Serum TGA } \\
\cline { 2 - 3 } & 0.137 & $p$ \\
\hline Fish & 0.026 & 0.386 \\
Meat & -0.071 & 0.757 \\
Bakery & -0.133 & 0.408 \\
Dairy & -0.165 & 0.295 \\
GUMP & -0.246 & 0.115 \\
Total & & 0.002 \\
\hline
\end{tabular}




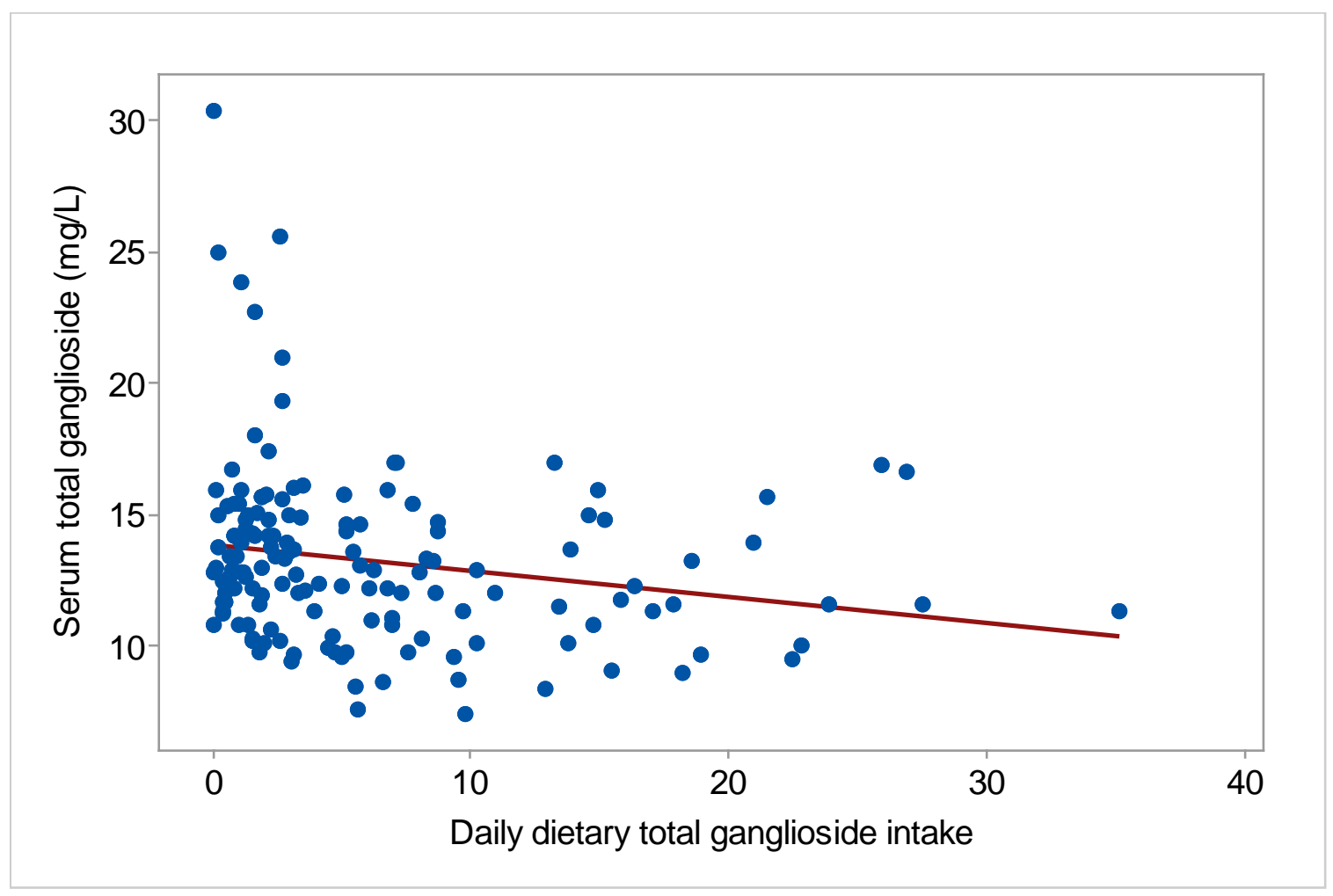

Figure 1. Regression plot of the serum TGA level against the dietary TGA intake for Indonesian toddlers. Spearman Rho correlation, $r=-0.246$, $\mathrm{p}=0.002$

\section{Discussion}

Increasing awareness of the roles that GAs play in human neurological development, immune system regulation and protection against enteric pathogens [4,7,8,9,10,11], particularly during the early stages of life, has recently led to a number of studies looking at the GA content in human milk and over lactation [12,13,24,25]. Although there is limited information on the dietary GA intake for infants, using the breast milk consumption data presented by Gurnida et al. [17] for the exclusively breast-fed Indonesian infant and the average GA levels in mature breast milk (18.5 mg/L [13]), the estimated daily TGA intake for Indonesian infants during the first 6 months ranged from 13.7 to $16.5 \mathrm{mg} /$ day, compared with $3.8-4.9 \mathrm{mg} /$ day for infants fed standard formula. Claumarchirant et al. [26] estimated the GA intake for formula-fed infants at 1.53-2.01 mg/day for Spanish infants, $1.77-2.32 \mathrm{mg} /$ day for Swedish infants and 1.16-1.53 mg/day for Czech Republic infants during their first 6 months of life [data converted from lipid-bound sialic acid (LBSA) to GD3 using an average molecular weight of 1540]. These levels are significantly lower than those reported by the Gurnida et al. [16] study.

In this study, the Indonesian toddlers consumed an average of $6.13 \pm 0.56 \mathrm{mg}$ TGA/day (Table 7). This was not significantly different $(p=0.76)$ compared to an average of $5.68 \pm 0.56 \mathrm{mg}$ TGA/day reported for Malaysian toddlers [14]. Both these intake levels are much lower than those typically measured for exclusively breast-fed infants.

The major source of dietary GA intake for the Indonesian toddler in this study was GUMPs $(4.4 \pm 0.57 \mathrm{mg} / \mathrm{day}$, $71.8 \%$ ). All the GUMPS consumed by these toddlers were based on bovine milk, having a TGA content ranging from
$2.80 \mathrm{mg} / 100 \mathrm{~g}$ to as high as $16.10 \mathrm{mg} / 100 \mathrm{~g}$. This range is consistent with those for other bovine-milk-based GUMPs reported in the literature $[27,28,29,30]$. The study by Khor et al. [14] also reported that GUMPs were the major source of dietary GAs (5.05 $\pm 56 \mathrm{mg} /$ day, 85\%) for Malaysian toddlers. However, a larger proportion (77\%) of the Malaysian toddlers consumed GUMPs, compared with only $61 \%$ (Table 2) of the Indonesian toddlers. The Malaysian toddlers also consumed goat-milk-based GUMPs, which were not consumed by any of the Indonesian toddlers. The goat-milk-based GUMPs had relative low levels of GAs compared with the bovinemilk-based GUMPs [14].

Meats and eggs contributed to $21 \%$ of the dietary TGAs and were the second major source of dietary GAs for the Indonesian toddlers. Although the Khor et al. [14] study also showed that meats and eggs were the second major source of dietary GAs for Malaysian toddlers, they made up only $6 \%$ of the dietary TGAs. The higher dietary GA contribution from meats and eggs observed for the Indonesian toddlers was related to the type of meat products consumed. Indonesian toddlers consumed a greater variety of offal, such as chicken and cow intestines and livers, and chicken gizzard and heart, which contains high levels of GAs (Table 4). The only offal tissue reported in the diet of the Malaysian toddlers was liver (chicken and bovine).

There was a wide spread in the GA content across the different dairy products $[0.59 \mathrm{mg} / 100 \mathrm{~mL}$ in UHT milk to $3.35 \mathrm{mg} / 100 \mathrm{~g}$ in cheese (Table 3)] consumed by the toddlers, contributing to $4.7 \%$ of the TGA intake for this Indonesian toddler cohort. Furthermore, dairy foods (excluding GUMPs) were not consumed by the Indonesian toddlers on a regular basis. For example, cheese was consumed only once or twice a month by the majority of 
toddlers, whereas UHT milk (flavoured or plain) was consumed 2-3 times a week. No yoghurts were consumed by the Indonesian toddlers during this study period.

Although fish is generally considered to be a staple food in Indonesia, its consumption was surprisingly low, with only $28 \%$ of the Indonesian toddlers eating fish during this study, compared with $83 \%$ of the Malaysian toddlers reported by Khor et al. [14]. It is unclear why this was the case. GAs from fish contributed only $1.3 \%$ of the dietary TGAs for the Indonesian toddlers.

Similar to fish, bakery foods did not contribute significantly to the dietary TGAs for this cohort $(0.8 \%$ of TGA intake). The majority of the bakery foods, including biscuit products, contained very low concentrations of GAs ( $<1 \mathrm{mg} / 100 \mathrm{~g}$ ). This was due to their plant-based ingredients, such as vegetable oils and wheat flour, which do not contain GAs.

Other than the Khor et al. study [14], the only other dietary GA intake study published was conducted in Canada, for a small group $(n=19)$ of adults from Edmonton, Alberta [31]. However, the results from this study were reported as LBSA ( $\mu \mathrm{g} N$-acetylneuraminic acid/day), ranging from 16 to $260 \mu \mathrm{g}(n=19)$, making comparison with the data from this study difficult. In contrast, Vesper et al. [32] estimated the total dietary intake of sphingolipids for the general USA population at $300-400 \mathrm{mg} /$ day. GAs make up only a small percentage (14.7\% of the total sphingolipids in dairy foods [33,34] and approximately 1.3 and $4.1 \%$ of the total sphingolipids in chicken (leg) and beef [35] respectively) of the sphingolipid intake. Using these values, the GA intake for the general USA population can be estimated to vary from as little $4 \mathrm{mg} /$ day to as high as $59 \mathrm{mg} /$ day.

The serum TGA levels for the toddlers varied from 7.4 to $30.4 \mathrm{mg} / \mathrm{L}$, with an average of $13.29 \pm 3.35 \mathrm{mg} / \mathrm{L}$. The serum TGA levels reported for the Malaysian toddlers ranged from 5.05 to $16.16 \mathrm{mg} / \mathrm{L}$, with an average of $9.7 \pm 2.57 \mathrm{mg} / \mathrm{L}$, which was significantly $(p<0.001)$ lower than that observed for the Indonesian toddlers in this study. It would be easy to hypothesize that the average GA serum levels are higher in Indonesian toddlers because of their higher average dietary TGA intake compared with Malaysian toddlers but further studies would be required. The only other serum TGA data reported in the literature are for adults. They vary across the studies, with Ma et al. [13] reporting maternal serum TGA levels ranging from $14.7 \pm 6.2$ to $19.6 \pm 9.4 \mathrm{mg} / \mathrm{L}$ and Senn et al. [36] reporting ranges of approximately 10.9-18.3 and 8.0-17.9 mg/L for six healthy males and five females respectively (TGAs estimated from LBSA, converting to $\mathrm{mg} / \mathrm{L}$ using an average molecular weight of the individual GAs reported). Although only limited serum GA data have been reported across different age groups, the current data set indicates that, within similar age groups, a wide spread of the serum TGA levels can be expected.

This study did not find any positive correlation between the dietary TGA intake and the serum TGA level, or at the individual food category (GUMPs, meat, dairy, fish, and bakery) level. Toddlers having a high dietary TGA intake did not always have a high serum TGA level. In fact, a weak negative correlation was observed. No correlation between dietary TGA intake and serum TGA was reported for a similar study for Malaysian toddlers [14]. However, for intervention studies, Gurnida et al. [16] reported a significant increase in the serum GA level for infants consuming approximately 12-16 mg TGA/day from infant formula containing high GA levels (at $1.71 \mathrm{mg} / 100 \mathrm{~mL}$ ), compared with the control group, where the infants consumed only 3.8-4.9 mg GA/day from standard infant formula containing GAs at $0.54 \mathrm{mg} / 100 \mathrm{~mL}$. Unlike the toddlers from this study, which were on a mixed diet, the infants in the Gurnida et al. [15] study were fed solely infant formula for 5-6 months. Similarly, in their intervention study, Miklavcic et al. [15] reported that the consumption of GAs at $43 \mathrm{mg} /$ day over 8 weeks increased the plasma content of GD3 by 35\%. The TGA intakes in these intervention GA studies [15,16,17] were much higher than the estimated dietary TGA intake for the Indonesian toddlers in this study. However, the GA contributions from breast milk, consumed by $35 \%$ of the toddlers during this study, were not taken into account. This may or may not have had an impact on the outcome of this study.

A number of other limitations of this study may have contributed to the lack of an observed correlation between the dietary GA intake and the blood GA level. Bloods were drawn from the toddler at times convenient to its parents. Given that $98 \%$ of GAs are transported in the serum lipoprotein fraction [36], which is known to display a metabolic diurnal variation for high density lipoprotein and low density lipoprotein cholesterol levels, how this diurnal variation impacts on serum GA levels in toddlers or adults remains unknown.

In this study, the daily dietary GA intake was estimated based on food frequency records taken over a 48-h period. Ideally, a longer dietary study would provide a better picture of the dietary food intake of these Indonesian toddlers.

Although current intervention studies indicate that higher levels of supplemented GA intake can have an impact on serum GA levels, the biological mechanism in place for controlling exogenous GA absorption in the gut and the endogenous biosynthetic processes in place to maintain GAs in tissues and/or blood are still unclear. Furthermore, the rate of GA turnover in the blood is also unclear. A lower serum GA status may not necessarily mean a lower dietary GA intake, as indicated in this study for some individuals (Figure 1), but may reflect the turnover/remodelling rate and the demand from the tissue/organ site, of perhaps be reflective of the longer term dietary GA intake status for individuals. GA levels in serum is probably controlled, so the cause and effect of dietary GA on serum may better be understood through a chronic GA feeding trial incorporating a dose response.

\section{Conclusions}

The Indonesian toddler's serum GA levels can vary widely and that the majority of the dietary GAs are sourced from GUMPs. A longer term study, as opposed to just a 48-h dietary survey as was conducted in this study, of the dietary GA intake of toddlers may be required to better understand the impact of the dietary GA intake on the serum GAs. 


\section{Declarations}

Ethics approval and consent to participate

The project was approved by the University of Indonesia Ethics Committee. The project aim was explained to all participating parents/guardians and signed written consents, allowing the child to be part of the study, for blood samples to be drawn and for results from the study to be published, were obtained.

\section{Competing Interests}

The authors declare that they have no competing interests.

\section{Funding}

This work was funded by Fonterra Co-operative Group, New Zealand.

\section{Acknowledgements}

The authors would like to thank the children and the parents who participated in this study, the staff from Prodia Clinical Research Organisation, Pasar Minggu, Jakarta 12540, Indonesia (Katherine Nadia and Amanda Nadhira for the many hours spent on recruitments, training of parents, monitoring, and assessing the daily food intake. The authors would also like to thank Ines Yumahana, Lisa Hall, Paul McJarrow and Alastair MacGibbon for discussion and review of this manuscript, Kevin Ma for assisting with the food GA analysis, and Claire Woodhall for editing the manuscript.

\section{List of Abbreviations}

GA: ganglioside; GUMP: growing-up milk powder; HPLC-MS: high performance liquid chromatography-mass spectrometry; LBSA: lipid-bound sialic acid; SE: standard error; TGA: total ganglioside.

\section{Ganglioside Nomenclature}

GM1: $\beta$ DGalp(1-3) $\beta$ DGalNAc $[\alpha \mathrm{Neu} 5 \mathrm{Ac}(2-$

3) $\beta$ DGalp(1-4) $\beta$ DGlcp (1-1)Cer

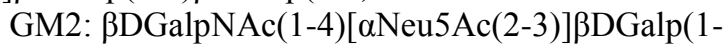
4) $\beta$ DGlcp (1-1)Cer

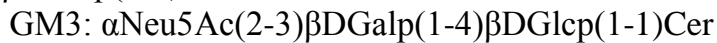

GD3: $\alpha$ Neu5Ac(2-8) $\alpha$ Neu5Ac(2-3) $\beta$ DGalp(1-

4) $\beta D G l c p(1-1)$ Cer

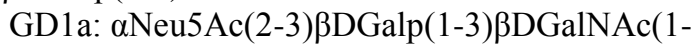

4) $[\alpha \mathrm{Neu} 5 \mathrm{Ac}(2-3)] \beta \mathrm{DGalp}(1-4) \beta \mathrm{DGlcp}(1-1) \mathrm{Cer}$

GD1b: $\beta$ DGalp(1-3) $\beta$ DGalNAc(1-4)[ $\alpha \mathrm{Neu} 5 \mathrm{Ac}(2-$

8) $\alpha$ Neu $5 \mathrm{Ac}(2-3)] \beta D G a l p(1-4) \beta D G l c p(1-1)$ Cer

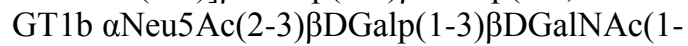
4) $[\alpha \mathrm{Neu} 5 \mathrm{Ac}(2-8) \alpha \mathrm{Neu} 5 \mathrm{Ac}(2-3)] \beta \mathrm{DGalp}(1-4) \beta \mathrm{DGlcp}(1-$ 1)Cer
GQ1b $=\alpha$ Neu5Ac(2-8) $\alpha$ Neu5Ac(2-3)ßDGalp $(1-$

3) $\beta$ DGalNAc (1-4) $[\alpha \mathrm{Neu} 5 \mathrm{Ac}(2-8) \alpha \mathrm{Neu} 5 \mathrm{Ac}(2-$

3)] $\beta D G a l p(1-4) \beta D G l c p(1-1)$ Cer

where

$\alpha \mathrm{Neu} 5 \mathrm{Ac}=5$-acetyl- $\alpha$-neuraminic acid is the sialic acid

$\beta$ DGalp = beta-D-galactopyranose

$\beta$ DGlcp $=$ beta-D-glucopyranose

$\beta$ DGalNAc $=N$-acetyl-beta-D-galactopyranose

Cer = ceramide (general $N$-acylated sphingoid).

\section{References}

[1] Albrecht S, van Muiswinkel GCJ, Schols HA, Voragen AGJ, Gruppen H. Introducing Capillary Electrophoresis with LaserInduced Fluorescence Detection (CE-LIF) for the Characterization of Konjac Glucomannan Oligosaccharides and Their in Vitro Fermentation Behavior. Journal of Agricultural and Food Chemistry, 57, 2009, pp. 3867-76.

[2] Svennerholm L. Chromatographic separation of human brain gangliosides. Journal of Neurochemistry, 10, 1963, pp. 613-23.

[3] International Union of Pure and Applied Chemistry and International Union of BM, Biology. Nomenclature of glycolipids (1997). Advances in Carbohydrate Chemistry and Biochemistry, 55, 2000, pp. 311-26.

[4] Palmano K, Rowan A, Guillermo R, Guan J, McJarrow P. The Role of Gangliosides in Neurodevelopment. Nutrients, 7, 2015, pp. 3891-913.

[5] Kolter T. Ganglioside biochemistry. International Scholarly Research Network, 2012, 2012, pp. 1-36.

[6] Svennerholm L, Bostrom K, Fredman P, Mansson JE, Rosengren B, Rynmark BM. Human brain gangliosides - developmental changes for early fetal stage to advanced age. Biochimica et biophysica acta, 1005, 1989, pp. 109-17.

[7] McJarrow P, Schnell N, Jumpsen J, Clandinin T. Influence of dietary gangliosides on neonatal brain development. Nutrition Reviews, 67, 2009, pp. 451-63.

[8] Ryan JM, Rice GE, Mitchell MD. The role of gangliosides in brain development and the potential benefits of perinatal supplementation. Nutrition Research, 33, 2013, pp. 877-87.

[9] Rueda R. The role of dietary gangliosides on immunity and the prevention of infection. British Journal of Nutrition, 98, 2007, pp. S68-S73.

[10] Rueda R. Gangliosides, immunity, infection and inflammation. In: Calder PC, Yaqoob P, editors. Diet, Immunity and Inflammation. Cambridge: Woodhead Publishing Ltd; 2013.

[11] Rueda R, Gil A. Role of gangliosides in infant nutrition. In: Huang YS, Sinclair AJ, editors. Lipids in Infant Nutrition. Champaign, IL.: AOCS Press; 1998. pp. 213-34.

[12] Ma L, Liu X, MacGibbon AKH, Rowan A, McJarrow P, Fong BY. Lactational changes in concentration and distribution of ganglioside molecular species in human breast milk from Chinese mothers. Lipids, 50, 2015, pp. 1145-54.

[13] Ma L, MacGibbon AKH, Jan Mohamed HJB, Loy S, Rowan A, McJarrow P, et al. Determination of ganglioside concentrations in breast milk and serum from Malaysian mothers using a high performance liquid chromatography-mass spectrometry-multiple reaction monitoring method. International Dairy Journal, 49, 2015, pp. 62-71.

[14] Khor GL, Shyam S, Misra S, Fong B, Chong MHZ, Sulaiman N, et al. Correlation between dietary intake and serum ganglioside concentratios: a cross-sectional study among Malaysian toddlers. BMC Nutrition, 2, 2016, pp. 1-13.

[15] Miklavcic JJ, Shoemaker GK, Schnabl KL, Larsen BMK, Thomson ABR, Mazurak VC, et al. Ganglioside Intake Increases Plasma Ganglioside Content in Human Participants. Journal of Parenteral and Enteral Nutrition, 41, 2017, pp. 657-66.

[16] Gurnida DA, Rowan AM, Idjradinata P, Muchtadi D, Sekarwana N. Association of complex lipids containing gangliosides with cognitive development of 6-month-old infants. Early Human Development, 88, 2012, pp. 595-601. 
[17] Gurnida DA, Idjradinata P, Muchtadi D, Sekarwana N, Fong B, McJarrow P, et al. Diet-induced changes in spectrum patterns of serum gangaliosides in 6-month-old Infants. Majalah Kedokteran Bandung, 44, 2012, pp.

[18] $\mathrm{Xu} \mathrm{X-Z,} \mathrm{Zhu} \mathrm{T-C.} \mathrm{Effect} \mathrm{of} \mathrm{gangliosides} \mathrm{in} \mathrm{repairing} \mathrm{the}$ neurological function of children with cerebral palsy: analysis of the curative efficacy in 2230 cases. Chinese Journal of Clinical rehabitation, 9, 2015, pp. 122-3 (in Chinese).

[19] Battistin L, Cesari A, Galligioni F, Marin G, Massarotti M, Paccagnella D, et al. Effects of GM1 ganglioside in cerebrovascular diseases: a double-blind trial in 40 cases. European neurology, 24, 1985, pp. 343-51.

[20] Svennerholm L, Brane G, Karlsson I, Lekman A, Ramstrom I, Wikkelso C. Alzheimer disease - Effect of continuous intracerebroventricular treatment with GM1 ganglioside and a systematic activation programme. Dementia and Geriatric Cognitive Disorders, 14, 2002, pp. 128-36.

[21] Schneider JS, Sendek S, Daskalakis C, Cambi F. GM1 ganglioside in Parkinson's disease: Results of a five year open study. Journal of the Neurological Sciences, 292, 2010, pp. 45-51.

[22] Nicolae I, Nicolae CD, Coman OA. Ganglioside serum levels prognostic significance in melanoma patients survival. Clinical Chemistry and Laboratory Medicine, 49, 2011, pp. S261-S.

[23] Fong BY, Ma L, Khor GL, van der Does Y, Rowan A, McJarrow $\mathrm{P}$, et al. Ganglioside Composition in Beef, Chicken, Pork, and Fish Determined Using Liquid Chromatography High-Resolution Mass Spectrometry. Journal of Agricultural and Food Chemistry, 64, 2016, pp. 6295-305.

[24] Giuffrida F, Elmelegy IM, Thakkar SK, Marmet C, Destaillats F. Longitudinal Evolution of the Concentration of Gangliosides GM3 and GD3 in Human Milk. Lipids, 49, 2014, pp. 997-1004.

[25] Thakkar SK, Giuffrida F, Cristina C-H, De Castro CA, Mukherjee $\mathrm{R}$, Tran L-A, et al. Dynamics of human milk nutrient composition of women from Singapore with a special focus on lipids. American journal of human biology: the official journal of the Human Biology Council, 25, 2013, pp. 770-9.

[26] Claumarchirant L, Matencio E, Sanchez-Siles LM, Alegria A, Lagarda MJ. Gangliosides content in infant formulas from three Europeam countries and the intake estimation. European Society for Paediatric Gastroenterology Hepatology and Nutrition Amsterdam, Netherlands 2015.

[27] Fong B, Norris C, McJarrow P. Liquid chromatography-highresolution electrostatic ion-trap mass spectrometric analysis of $\mathrm{GD}(3)$ ganglioside in dairy products. International Dairy Journal, 21, 2011, pp. 42-7.

[28] Pan XL, Izumi T. Variation of the ganglioside compositions of human milk, cow's milk and infant formulas. Early Human Development, 57, 2000, pp. 25-31.

[29] Sanchez Diaz A, Ruano MJ, Lorente F, Hueso P. A critical analysis of total sialic acid and sialoglycoconjugate contents of bovine milk-based infant formulas. Journal of Pediatric Gastroenterology and Nutrition, 24, 1997, pp. 405-10.

[30] Sorensen LK. A liquid chromatography/tandem mass spectrometric approach for the determination of gangliosides GD3 and GM3 in bovine milk and infant formulae. Rapid Communications in Mass Spectrometry, 20, 2006, pp. 3625-33.

[31] Pham PH, Duffy T-L, Dmytrash AL, Lien VW, Thomson AB, Clandinin MT. Estimate of dietary ganglioside intake in a group of healthy Edmontonians based on selected foods. Journal of Food Composition and Analysis, 24, 2011, pp. 1032-7.

[32] Vesper H, Schmelz EM, Nikolova-Karakashian MN, Dillehay DL, Lynch DV, Merrill AH. Sphingolipids in food and the emerging importance of sphingolipids to nutrition. Journal of Nutrition, 129, 1999, pp. 1239-50.

[33] Rombaut R, Camp JV, Dewettinck K. Analysis of phospho- and sphingolipids in dairy products by a new HPLC method. Journal of Dairy Science, 88, 2005, pp. 482-8.

[34] Fong B, Ma L, Norris C. Analysis of phospholipids in infant formulas using high performance liquid chromatography-tandem mass spectrometry. Journal of Agricultural and Food Chemistry, 61, 2013, pp. 858-65.

[35] Hellgren LI. Occurrence of bioactive sphingolipids in meat and fish products. European Journal of Lipid Science and Technology, 103, 2001, pp. 661-7.

[36] Senn HJ, Orth M, Fitzke E, Wieland H, Gerok W. Gangliosides in normal human serum - concentration, pattern and transport by lipoproteins. European Journal of Biochemistry, 181, 1989, pp. 657-62.

(C) The Author(s) 2019. This article is an open access article distributed under the terms and conditions of the Creative Commons Attribution (CC BY) license (http://creativecommons.org/licenses/by/4.0/). 